\title{
Mykhailo Hrushevskyi’s Father: Biographical Aspects
}

\section{Author(s): Yaryna Yurynets}

Source: Kyiv-Mohyla Humanities Journal 4 (2017): 11-27

Published by: National University of Kyiv-Mohyla Academy

http://kmhj.ukma.edu.ua/ 


\title{
Mykhailo Hrushevskyi's Father: Biographical Aspects
}

\author{
Yaryna Yurynets \\ National University of Kyiv-Mohyla Academy, \\ Department of Philosophy and Religious Studies
}

\begin{abstract}
The key scholarly issue of contemporary Ukrainian research is not only a return to existing problems and figures but also a search for new figures and the filling of historical and biographical gaps. The present article is dedicated to the biography of Kyiv Theological Academy graduate Serhii Hrushevskyi (1830-1901), a figure who has rarely appeared in research previously. He was a talented teacher and gained credibility and respect among his contemporaries. More attention should be paid to his publications in periodicals, the themes of which varied from pedagogy to linguistics. It is necessary to emphasize the importance of Hrushevskyi in the development of public education of the late 19th century. The education, hard work, and active social activity of Serhii Hrushevskyi had a positive impact on his son, renowned Ukrainian politician and statesman, historian Mykhailo Hrushevskyi (1866-1934), for whom his father was his first and major mentor. Love for "Ukrainians," learning and writing, selfless work — is the legacy that Serhii Hrushevskyi passed on to Mykhailo, which was always at the core of his life and scholarly activity. The results of the article not only contain new biographical information about Hrushevskyi's family, but also emphasize the significant role of the biographical component in modern scholarly research.
\end{abstract}

Key Words: Kyiv Theological Academy, Serhii Hrushevskyi, Mykhailo Hrushevskyi, public education, Shevchenko Scientific Society (Naukove Tovarystvo imeni Shevchenka), Literary and Scientific Bulletin (Literaturno-naukovyi visnyk).

\section{唡}

Even though researchers have long payed attention to prominent Ukrainian historian and statesman Mykhailo Serhiiovych Hrushevskyi, only in recent years have his family and, particularly, the life and creative work of his father, Serhii Fedorovych Hrushevskyi, a renowned pedagogue and public activist of the second half of the 19th century and graduate student of Kyiv Theological Academy, been researched. ${ }^{1}$ The factual material describing this outstanding

See M. O. Kucherenko, "Dilu semu posviatyv vin vseiu dusheiu [Matters that He Devoted His Heart and Soul to]," in Ya buv yikh starshyi syn (simia Mykhaila Hrushevskoho), ed. M. O. Kucherenko, S. M. Pankova and H. V. Shevchuk (Kyiv: Kyi, 20o6), 74-123; M. Kucherenko, "Serhii Fedorovych Hrushevskyi: etapy zhyttia i diialnosti na nyvi pedahohiky [Serhii Fedorovych Hrushevskyi: Stages of Life and Work in the Field of Pedagogy]," Ukrainoznavstvo 1 (2016):33-45; S. A. Zhuravlev, "Stanovlennia i rozvytok osvitianskoi diialnosti Serhiia Fedorovycha Hrushevskoho u druhii polovyni XIX st. [The Establishment and Development of the Educational Activity of S. F. Hrushevskyi 
figure is far from complete in presenting all aspects of his biography. Taking this into account, the proposed article specifies the biography of S. F. Hrushevskyi and traces his influence on the work of Mykhailo Serhiiovych Hrushevskyi, especially during the formation of his worldview and his cultural projects at the beginning of the 2oth century (the work of the Shevchenko Scientific Society and publication of Literaturno-naukovyi visnyk (Literary and Scientific Bulletin)).

Serhii Hrushevskyi was born on 7 (19) October 1830 in Chyhyryn, Kyiv province (today a district center of Cherkasy oblast), in the large family of Fedir Vasyliovych Hrushevskyi, a deacon (later priest) at the local cathedral church of the Exaltation of the Holy Cross. Serhii's mother, Mariia Kyrylivna (maiden name Botvynovska), was the daughter of a priest. In 1844, S. F. Hrushevskyi entered Kyiv-Podilsk religious school. After graduation, he studied at Kyiv Theological Seminary, from 1849 to 1855. In 1851, he lost his father, after whose death his mother and younger brothers found themselves in strained circumstances. Serhii Hrushevskyi remembered this difficult period his entire life. Later, having his own children, he "sometimes consciously tried to teach [them]... to manage with the smallest means, and sometimes unconsciously shared this by personal example." ${ }^{2}$

Hrushevskyi would demonstrate his obligation to the family later, while at that time, the young man felt himself responsible to obtain a further education. His efforts did not turn out to be futile - after successful graduation from the seminary in autumn 1855 , he entered the Kyiv Theological Academy (KTA). "For those times, for that poor father's circumstances," wrote his son Mykhailo later, "it was an unusual, unbelievable, and triumphal success. My father should have thought of himself as a favorite of fortune." ${ }^{3}$

Successfully graduating from the Academy as a Master of Theology and Philology ${ }^{4}$ the degree was awarded to him by a Kyiv Theological Academy Conference on 7 August 1859 and confirmed by the Sacred Governing Synod on 8 October of the same year), S. F. Hrushevskyi was appointed to the Poltava Theological Seminary as a teacher of philology. ${ }^{5}$ In the summer of 1860, he returned to Kyiv, being appointed to the Kyiv Theological Seminary as a professor in Holy Scripture (June 23). ${ }^{6}$

in the Second Half of the 19th Century]," Zbirnyk naukovykh prats Kharkivskoho natsionalnoho pedahohichnoho universytetu imeni H. S. Skovorody 48 (2013): 202-08; Ya.I. Yurynets, "Hrushevskyi Serhii Fedorovych," in Kyivska dukhovna akademiia v imenakh, vol. 1, ed. M. Tkachuk (Kyiv: Vydavnychyi dim "Kyievo-Mohylianska akademiia," 2015), 410-12.

$2 \quad$ M. S. Hrushevskyi, "Spohady [Memoirs]," Kyiv 12 (1988): 116. All translations from Ukrainian are mine.

3 Hrushevskyi, "Spohady," 118.

4 The last part of S. F. Hrushevskyi's manuscript, Istoriia khristianskoi propovediv Kitae (The History of Christian Preaching in China), is not preserved.

Zhurnal zasedanii Konferentsii Kievskoi dukhovnoi akademii za 1859 god [Conference Journal of the Kyiv Theological Academy of in 1859] [Manuscript] (Manuscript Institute, V. I. Vernadskyi National Library of Ukraine, f. 175, no. 59/7, pp. 1007-o9, 1013); Zhurnal zasedanii Konferentsii Kievskoi dukhovnoi akademii za 1860 god [Conference Journal of the Kyiv Theological Academy in 1860] [Manuscript] (Manuscript Institute, V. I. Vernadskyi National Library of Ukraine, f. 175, no. 59/8, pp. 1035).

6 Hereinafter the dates of changes of S. F. Hrushevskyi's positions received from his record of service of 1910 year (S. F. Hrushevskyi, "Svidotstvo pro narodzhennia, posluzhni spysky ta biohrafiia [Birth 
Being able to care for his younger brothers and sisters thanks to his professor's status, Serhii Fedorovych helped his youngest brother Ihnatii to enter the seminary, and helped his brother Ivan "who did not go far in his studies, to become a deacon in Pyrohov near Lisnyky. He arranged for his younger sister Mariia to marry a priest, for whom he found a decent parish near Kyiv. Serhii gave shelter to his mother at his home to live out her days." ${ }^{7}$ Mykhailo Serhiiovych commented on his feeling of family obligations and responsibility, inspired by his father's example:

Finally, I created a peculiar religion of family for myself; I took as a principle the responsibility to love my closest ones, first of all, my parents, brothers and sisters, no matter what, to worry for their life and health, to serve and take care of them, and, in the first place, to appreciate the opportunity to live together and to be pleased with this as the highest level of happiness. ${ }^{8}$

Immersed in pedagogical activities and family worries, S. F. Hrushevskyi found time for writing periodic articles. From 1860 to 1865 he was one of the regular contributors to the journal Rukovodstvo dlia selskikh pastyrei (Instructions for Rural Pastors), published at the seminary on the initiative of F. H. Lebedyntsev, ${ }^{9}$ with whom S. F. Hrushevskyi maintained friendly relations his entire life..$^{10}$ The themes of his articles were wide: from ethnographic studies, ${ }^{11}$ which he could not ignore since "he sincerely loved the Ukrainian folk element"12 and the day's pressing issues

Certificate, Service Record and Biography]," (1830-1901) [Manuscript] (Central State Historical Archives of Ukraine in Kyiv, f. 1235, desc. 1, no. 1, pp. 14-25).

7 Hrushevskyi, "Spohady," 118.

8 Hrushevskyi, "Spohady," 145.

9 Kyiv Theological Academy graduate (1847-1851) Feofan Havrylovych Lebedyntsev (1828-1888) was a famous cultural figure, teacher, publisher, historian, and writer. In 186o-1863 he was an editor and one of the authors of the journal Rukovodstvo dlia selskikh pastyrei, which described the pastoral and educational activity of the clergy, contained ethnographic studies of "people's Orthodoxy," pre-Christian traditions and rituals, homiletic writings, and others. (See S. L. Kuzmina, "Lebedyntsev Feofan Havrylovych," in Kyivska dukhovna akademiia v imenakh, vol. 2, ed. M. Tkachuk (Kyiv: Vydavnychyi dim “Kyievo-Mohylianska akademiia," 2016), 50-53.)

10 Feofan Lebedyntsev's first wife Julia (born Barska, $† 1868$ ) was Mykhailo Hrushevskyi's godmother.

11 S. F. Hrushevskyi, "Ostatki yazychestva v nashem prostom narode [Remains of Paganism Among Our Common Folk]," Rukovodstvo dlia selskikh pastyrei 41 (1860): 131-50; S. F. Hrushevskyi, "O nekotorykh sviatochnykh obychaiakh prostoho naroda [About Some Holy Customs of Commoners]," Rukovodstvo dlia selskikh pastyrei 52 (1861): 623-42; S. F. Hrushevskyi, "Po povodu prostonarodnykh primet v den Novogo goda [About New Year's Superstitions Among Commoners]," Rukovodstvo dlia selskikh pastyrei 1 (1862): 6-24; S. F. Hrushevskyi, "Suevernaia vstrecha prazdnika Paskhi u yuzhno-russkikh prostoliudinov [Easter Superstitions Among South Russian Commoners]," Rukovodstvo dlia selskikh pastyrei 18 (1862): 6-16; S. F. Hrushevskyi, "Sovremennye prostonarodnye verovaniia otnositelno vedunstva i koldovstva [Modern Commoner's Beliefs Regarding Witchcraft and Magic]," Rukovodstvo dlia selskikh pastyrei 21 (1865): 105-20; 25 (1865): 263-80. 
relating to theological education, ${ }^{13}$ to Russian church history ${ }^{14}$ and juridical norms of last will legalization..$^{15}$

The tranquil Kyivan life of S. F. Hrushevskyi ended with the social and political events connected to the Polish national liberation uprising of 1863-1864. After tackling it, the government of the Russian Empire started to embody a large-scale program of Russification and Orthodoxy promotion in the dependent territories of the Kingdom of Poland. The realization of this program, first and foremost, required skilled pedagogical personnel, which began with the recruitment of two respectable professors of the Kyiv Theological Academy: Feofan Lebedyntsev and Yukhym Kryzhanovskyi. ${ }^{16}$

One of those who accepted F. H. Lebedyntsev's proposal to change his place of work was S. F. Hrushevskyi: from 23 September 1865, he occupied the position of Russian philology teacher at the Kholm Gymnasium. Before his departure to the Kingdom of Poland, Hrushevskyi married the 17-year-old daughter of a peasant priest, Hlafira Zakhariivna Oppokova. ${ }^{17}$ One of her main traits was "a strongly developed moral asceticism," which "was embodied in her piety,

13 S. F. Hrushevskyi, "K voprosu ob izyskanii sposobov k uluchsheniiu materialnoho byta dukhovnykh uchilishch [Regarding the Question of the Search for the Ways of Material Improvement in Theological Schools]," Rukovodstvo dlia selskikh pastyrei 47 (1862): 442-43; S. F. Hrushevskyi, "Po voprosu o narodnom obrazovanii [On the Question of Public Education]," Rukovodstvo dlia selskikh pastyrei 42 (1863): 319-25.

14 S. F. Hrushevskyi, "Istoricheskiie svedeniia o chyne mirovareniia [Historical Information About the Mass of the Chrism]," Rukovodstvo dlia selskikh pastyrei 44 (1863): 314-20; S. F. Hrushevskyi, "Krestnye khody v Russkoi Tserkvi [Processions of the Cross of the Russian Church]," Rukovodstvo dlia selskikh pastyrei 46 (1863): 482-95; 49 (1863): 617-31; S. F. Hrushevskyi, “Otmenennye tserkovnye obriady i chinoposledovaniia vremen patriarshestva v Rossii [Canceled Church Ceremonies and Clerical Ranks in the Times of the Patriarchate in Russia]," Rukovodstvo dlia selskikh pastyrei 23 (1863): 173-90; 28 (1863): 363-80; 35 (1863): 1-19; 38 (1863): 133-46; 39 (1863): 171-81; S. F. Hrushevskyi, "Obriady pravoslaviia pri moskovskikh Mitropolitakh i Patriarkhakh Vserossiiskikh [Orthodox Ceremonies of Moscow Metropolitans and Patriarchs]," Rukovodstvo dlia selskikh pastyrei 11 (1864): 367-77; S. F. Hrushevskyi, "Prazdnik Bohoiavleniia v Rossii v XVI i XVII stoletiiakh [The Feast of the Epiphany in Russia in the 16th and 17th Centuries]," Rukovodstvo dlia selskikh pastyrei 2 (1864): 33-51.

15 S. F. Hrushevskyi, "O dukhovnom zaveshchanii [About Spiritual Testament]," Rukovodstvo dlia selskikh pastyrei 51 (1864): 653-58; $5^{2}$ (1864): 733-44.

16 Yukhym Mykhailovych Kryzhanovskyi, a graduate of Kyiv Theological Academy (1853-1857) was a renowned pedagogue, educator, and historian of the Church. He was a teacher at the Kyiv Theological Seminary from 1858 to 1862 . From 1862 to 1864 , he held the position of General and Russian literature at Kyiv Theological Academy. See M. V. Yaremenko, "Kryzhanovskyi Yukhym/ Yevfymii Mykhailovych," in Kyivska dukhovna akademiia v imenakh, vol. 1, ed. M. Tkachuk (Kyiv: Vydavnychyi dim "Kyievo-Mohylianska akademiia," 2015), 722-25.

17 Serhii Hrushevskyi married Hlafira Oppokova (1847-1918) on 5 (17) August 1865 in Sviato-Pokrovskyi Church, the village of Sestrynivka, Berdychivskyi povit, Kyiv province (today the Koziatyn district of Vinnytsia oblast). See Kucherenko, "Dilu semu posviatyv vin vseiu dusheiu," 34. 
an unusually firm and merciless carrying out of various religious duties." ${ }^{18}$ From his mother Mykhailo Hrushevskyi inherited "a need for strong feelings, painful, rather than joyful" and "an acute course of piety." 19

During his service in Kholm (which used to belong to Lublin province of the Kingdom of Poland as part of the Russian Empire, and today belongs to Lublin Voivodeship of the Republic of Poland), Serhii Hrushevskyi concentrated on teaching and administrative work. It was here, "on the night of 17 (29) September 1866, in the Piarist houses where the seminary used to be" and where the young family lived, that the first child, Mykhailo, was born. ${ }^{20}$

Having lived in Kholm for three years, on 1 November 1868, S. F. Hrushevskyi received a new position as a philology teacher in the men's classical gymnasium of the principal town of the province, Lomzhi (today a town in Podlaskie Voivodeship of the Republic of Poland). However, after only two months he had to ask for dismissal because of the bad state of his health. At the beginning of 1869, Hrushevskyi took his wife and son to his father-in-law in Sestrynivka village near Kyiv, and listening to his doctors' advice, moved to work in Kutaisi (Georgia), where he taught Russian language and philology at the local classical gymnasium.

Numerous trips to Sestrynivka took place in the following years, each stamped in Mykhailo Hrushevkyi's memory: "Impressions of the trip, of the Ukrainian village, of those people whom I got to see, were so numerous, that they crowded and trampled themselves in my memory." ${ }^{21}$ During his studentship, Mykhailo made those trips on his own. On one such visit in 1882, he found the remnants of his father's library,

(They) were arranged in a giant chest in some closet and which now came to light. Its contents were diverse: fragments of an old 18th century book, Russian journals of the 186os (Russkoe Slovo (Russian Word), a radical monthly magazine), and a handwritten collection of the "sacred priest Danyil Hyrman" from the Bohushkova settlement near Zolotonosha, dating back to the first quarter of the 18 th century.22

That discovery was extremely valuable: as Mykhailo Hrushevskyi recollected, "apart from deepening my sympathy for and interest in Ukrainian antiquity, those books were the first to give me some understanding of the contemporary state of Ukrainian life and the Ukrainian movement." ${ }^{23}$ Having noticed his son's literary fascinations, his father made Mykhailo "a very appropriate present, which had a great impact on the following developments" of his interests and "made way... for further activities": he subscribed to the periodical Kievskaia starina (Kyivan Antiquity) for 1882 and the following year. ${ }^{24}$

\footnotetext{
18 Hrushevskyi, "Spohady," 120.

19 Hrushevskyi, "Spohady," 120.

20 Hrushevskyi, "Spohady," 121.

21 Hrushevskyi, "Spohady," 137.

22 Hrushevskyi, "Spohady," 119.

23 Hrushevskyi, "Spohady," 120.

24 Hrushevskyi, "Spohady," 119-2o.
} 
On 9June 1870, Serhii Hrushevskyi became an inspector of primary schools in newly formed Stavropol province (today the Stavropol Krai of the Russian Federation). He took the family there from Kyiv province (their daughter Hanna was born on 4 April 1870), ${ }^{25}$ including his elderly mother (who passed away around 1871). It was there, in the Stavropol region, where he finally found his true vocation through active participation in the organization of the primary school.

Because of the poor development of school education in the region, S. F. Hrushevskyi had to make frequent trips to villages to convince local communities in the need for education and to encourage them to financially support school construction and maintenance. On those trips, Serhii Fedorovych welcomed the opportunity to talk to people, especially to the representatives of Ukrainian communities: "He missed Ukraine, the Ukrainian people and language, and felt comfortable in Ukrainian villages, where he could talk to peasants in Ukrainian. He was especially willing to cultivate Ukrainian song in the schools." ${ }^{26}$ Mykhailo Hrushevskyi warmly recalls his father returning home from his frequent and prolonged assignments: "All of us were happy about his return; with it our rooms became as if filled with the inspiration of those boundless steppes covered with flowers and grass where he spent entire weeks on the road." ${ }^{27}$

S. Hrushevskyi also took care of the preparation of pedagogical personnel, helping to open a pedagogical class at the local women's classical gymnasium because "at that time there were not many teaching seminaries and one could hardly find male or female teachers with seminarian training." 28

And since everything Serhii Fedorovych did, "he did with love, with taste, thoroughly, systematically, and bringing every work to a close," ${ }^{29}$ his efforts were fruitful:

Having found a barren field in the school sphere in eight years his father had left behind well-organized school management, with over 100 wellestablished schools, very decent teaching personnel, and a wide-ranging pedagogical inventory. ${ }^{30}$

In the end, S.F. Hrushevskyi's pedagogical enthusiasm began to irritate the provincial government, and on 18 August 1878 he had to take a new position as a director of primary schools in Vladikavkaz (today the Republic of Ossetia-Alania in the Russian Federation) in the neighboring Tver oblast, where he had to initiate the development of education from the very beginning.

Dedicating much time to educational matters in which "he invested... all of himself," ${ }_{1}$

25 Hanna Serhiivna Hrushevska (Shamrai) (1869-1943) was Ukrainian historian, translator, and public service employee. In the 1920 s worked in the Standing Committee for completing historical and geographical dictionary of Ukrainian lands of Ukrainian Academy of Sciences, soon was fired because of the repressions in 193os.

26 Hrushevskyi, "Spohady," 126.

27 Hrushevskyi, "Spohady," 132.

28 Hrushevskyi, "Spohady," 125.

29 Hrushevskyi, "Spohady," 125.

$30 \quad$ Hrushevskyi, "Spohady," 126.

31 Hrushevskyi, "Spohady," 125. 
S. F. Hrushevskyi did not forget about his own children, ${ }^{32}$ being especially active in the life of his eldest son, Mykhailo. It was he who needed most support in the $188 \mathrm{os}$, as the younger children remained with their parents (at that time his daughter Hanna was finishing Vladikavkaz women's classical gymnasium, and his son Oleksandr ${ }^{33}$ was only beginning primary school), whereas Mykhailo Hrushevskyi was studying far away from home, in the Tiflis (today Tbilisi, Georgia) seminary. Serhii Fedorovych strongly objected to studying at the local real school, "being a firm supporter of the humanities school, believing that practical knowledge and work were less serious and respectful than studies in the humanities," ${ }^{34}$ while his son "did not dare to rise up against his father's intentions." 35

Being separated from his family was a very difficult experience for young Mykhailo, who later recalled that "Grief and fear embraced my poor soul." ${ }^{36}$ At first, he had conflicts with his schoolmates but later gained authority at the gymnasium, mainly due to his successful academic performance. Mykhailo Hrushevskyi mentions his gymnasium teachers in great detail. Among them was a renowned Ukrainian scholar, one of the founders of the Brotherhood of Saints Cyril and Methodius, Mykola Ivanovych Hulak, who "instead of spiritual compositions, left for Ukrainians a model of moral dignity, noble resignation and fortitude." 37

Having finished Tiflis gymnasium in 1886, M. S. Hrushevskyi moved to Kyiv, where he entered the historical department of the faculty of history and philology at St. Volodymyr Universtity.

Hrushevskyi's family made a good fortune abroad — Serhii Fedorovych purchased a house with a plot of land, which he turned into "a wonderful garden with beautiful flowers, vegetable patches, and plantations of grapes and berries." 38 Lines from his last will serve as evidence of the special attention S. F. Hrushevskyi's paid to his garden:

My country garden, which I planted myself, which I moulded with love and which is, thus, so dear to me, must ... stay within my family, within its male line, as long as possible, in memory of myself among my offspring. ${ }^{39}$

Serhii and Hlafira Hrushevski had seven children, however, they had to live through the deaths of four of them: youngest daughter Mariia (1880-1882), sons Zacharii (1872-1882) and Fedir (1875-1882), and infant son Vasyl (1886).

Oleksandr Serhiiovych Hrushevskyi (1877-1942) — historian, literary critic, and civil servant. He taught in Novorossiysk, Moscow, and at St. Petersburg University. In 1938 was arrested by the NKVD and was sentenced as a participant of an "Anti-Soviet Ukrainian national terrorist organization." He died in exile in Pavlodarsk region, Kazakhstan. See L. Kleyzun, "Do biohrafii Oleksandra Hrushevskoho [On the Biography of O. Hrushevskyi]," Kraieznavstvo 1-2 (2000): 65-69. Hrushevskyi, "Spohady," 144.

35 Hrushevskyi, "Spohady," 145.

36 Hrushevskyi, "Spohady," 145.

37 Hrushevskyi, "Spohady," 128.

38 Hrushevskyi, "Spohady," 126.

39 S. F. Hrushevskyi, "Zapovit [Testament]," 1892 [Manuscript] (Central State Historical Archives of Ukraine in Kyiv, f. 1235, desc. 1, no. 11, pp. 18 back). All translations from Russian are mine. 
With a heavy heart, S. F. Hrushevskyi permitted his elder son to move to Kyiv, and later, to Lviv which "was an awful mess." 40 "He was afraid," as M. S. Hrushevskyi recalled, "that with all my 'Ukrainophilism' (a word that sounded dangerous and ominous at the time), I would most definitely get into a 'khokhloman' mess." ${ }^{41}$ However, he later accepted the situation and supported Mykhailo in his studies and further academic work in every possible way, becoming an active participant in and sponsor of all his cultural undertakings. Mykhailo Serhiiovych never forgot about his father's surveillance, "the close connection... with my father, which was with me throughout the following years... had a great impact on the formation of my character." ${ }^{42}$

After defending his Masters dissertation at St. Volodymyr University in 1894, young Mykhailo moved to Lviv, where he received an appointment as Ordinary Professor at the Department of World History with a specialty in the history of Eastern Europe. It was there, in Lviv, that M. S. Hrushevskyi was able to reveal all his academic and organizational potential, garnered since his studies at the gymnasium, "I reared a strong personality cult in myself; I dreamed of overcoming all circumstances throughout my life to reach the goal which I set for myself - a perfect public character." 43 Along with that, the impact of his father's figure was clearly felt in every sphere of his life: in borrowing experience, in following a well-grounded approach to work, in choosing an arena of interest.

While teaching at the university, M. Hrushevskyi began active collaboration with the Shevchenko Scientific Society (Naukove Tovarystvo imeni Shevchenka), where he was already Head of the Historical and Philosophical Section and of the Archaeographical Commission (which he himself created). The Shevchenko Literary Society (which became the Shevchenko Scientific Society in 1892) was founded in Lviv on the initiative of historian Volodymyr Antonovych and writer Oleksandr Konysky back in $1873,{ }^{44}$ but its golden age coincided exactly with the leadership of Hrushevskyi (1897-1913), who became the eighth head of the organization. M. Hrushevskyi saw the prospects for the development of the Shevchenko Scientific Society in its transformation into a multi-sectoral academy of sciences. This transformation could be facilitated by the existing division into sections (Historical-Philosophical, Philological, and Mathematical-Natural Science-Medical) and commissions (in the 1920s there were enough of them: on Archaeography,

$40 \quad$ H. Z. Hrushevska (Oppokova), "Letter from H. Z. Hrushevska to M. S. Hrushevskyi from 3 January 1897," [Manuscript] (Central State Historical Archives of Ukraine in Kyiv, f. 1235, desc. 1, no. 278, p. 427).

41 Hrushevskyi, "Spohady," 138.

42 Hrushevskyi, "Spohady," 124.

43 Hrushevskyi, "Spohady," 138.

44 After the liquidation of the Shevchenko Scientific Society (Naukove Tovarystvo imeni Shevchenka, NTSH) by the Soviet government during the liquidational assembly on 14 January 1940, its activity was reopened abroad. At the general meeting, which took place in Munich on 9 April 1949, the central chapter of the NTSH, under whose leadership the chapters in the USA (The Shevchenko Scientific Society in the US, 1948), in Canada (Shevchenko Scientific Society of Canada, 1949) and in Australia (Shevchenko Scientific Society in Australia, 1950) appeared. After the relocation of the central chapter of the NTSH (later - Supreme Council of the NTSH) to France on March $195^{2}$ the European chapter of the fellowship appeared. On 16 November 1989 the activity of the Shevchenko Scientific Society was reactivated in Ukraine. 
Bibliography, Geography, Ethnography, the History of Arts, Classical Philology, Shevchenko Studies, Science and Technology, Law, Statistics, Oriental studies, Language, and Physiography). Under his guidance, a new statute of the society was approved on 2 February 1898 , which charted a number of innovations; specifically, it clearly divided all members of the society into full (scholars) who were required to have qualifications and ordinary, "non-scholars," who were left with only advisory votes in academic and organizational affairs.

Serhii Fedorovych Hrushevskyi repeatedly expressed his active support of his son in his letters to him on the issue of the society's reorganization. Later, in an obituary notice, Mykhailo would mention his father as "a member and founder of the Shevchenko Scientific Society." 45

1901, in the Chronicles of the Shevchenko Scientific Society, saw the publication of "Vidozva do ukraiintsiv u spravi zboru istorychnykh pamiatok (A Response to Ukrainians on the Issue of the Gathering Relics from the Past)," 46 which gave rise to the systematization of the Ukrainian Culture Museum at the Shevchenko Scientific Society. Even though the museum had formally functioned since 1893, it existed only as a small and unarranged collection of exhibits. Mykhailo Hrushevskyi himself began to inventorize and systematize the museum, which following the "Vidozva" publication began to be actively replenished with new exhibits. These responsibilities were a pleasure for the young Hrushevskyi because back in his Stavropol childhood he had "rushed to collect various things, collecting them with unique vigor" 47 and "following the example of his father's bookkeeping, ... made his own records, collected different papers, kept accounts of his small capital, prepared monthly statements of his income and expenditures, which he bound together and fixed with a seal." 48 Meanwhile, in the arrangement of museum exhibits he showed "pronounced affection for the Ukrainian element," 49 which he thought to be "fully inherited from his father." 50

Immediately after being elected as Head of the Shevchenko Scientific Society (1898), M. S. Hrushevskyi initiated the publication of the first Ukrainian literary-scholarly and publicpolitical periodical, Literaturno-naukovyivisnyk, where he was the chief editor (until 1907 together with Ivan Franko). ${ }^{51}$ Its pages became the place of publication for renowned Ukrainian writers from Halychyna and Dnieper Ukraine ${ }^{52}$ (I. Franko, Lesia Ukrainka, I. Nechui-Levytskyi, O. Kobylianska,

45 "Nekroloh [Obituary] [Hrushevskyi S. F.]," Literaturno-naukovyi visnyk 13 (1901): 220.

46 "Vidozva do ukraiintsiv u spravi zboru istorychnyh pamiatok [A Response to Ukrainians on the Issue of the Gathering Relics from the Past]," Khronika Naukovoho Tovarystva Imeni Shevchenka 8.4 (1901): 18.

47 Hrushevskyi, "Spohady," 127.

48 Hrushevskyi, "Spohady," 127.

49 Hrushevskyi, "Spohady," 120.

$50 \quad$ Hrushevskyi, "Spohady," 120.

51 Literaturno-naukovyi visnyk was published from January 1898 to December 1906 in Lviv, from January 1907 to July/August 1914 and from July 1917 to July/September 1919 in Kyiv. From 1933 to 1939 the Visnyk literatury, mystetstva, nauky i hromadskoho zhyttia was published as a continuation of the Literaturno-naukovyi visnyk (Editor-in-Chief — Dmytro Dontsov).

The publication of the Ukrainian monthly magazine the Literaturno-naukovyi visnyk had allUkrainian importance, because of prohibition of Ukrainian periodicals in the Russian Empire (the Valuev Circular of 1863, the Ems Decree of 1876). 
V. Vynnychenko), for translations of foreign authors (E. A. Poe, E. Zolia,J. W. Goethe), for journalistic and scholarly works, reviews, and even obituary notices. It was a successful attempt to consolidate Ukrainian intellectuals in order to activate a national literary and cultural renaissance. Editing and systematizing fascinated M. Hrushevskyi because, as he confessed, "books and publishing" remained "the largest and most persisting passion of all my life." ${ }^{33}$ In his publishing, his father's experience, who himself had published and distributed his own textbook on the Church Slavonic language for primary schools back in the 1870 (Pervaia uchebnaia kniga tserkovnoslavianskoho yazyka (The First Student's Book of the Church Slavonic Language)), ${ }^{54}$ and who had actively carried on correspondence with publishers, printing offices, and bookshops, proved useful. ${ }^{55}$

Serhii Fedorovych wrote to express his congratulations to his son, "I received a notice that you, in Galicia, will have new issues of the Literaturno-naukovyi visnyk from the beginning of the new year. Of course, one cannot help but be happy for the birth of a new literary organ." 56 Perhaps it was in consideration of Mykhailo's achieved experience in publishing that his father trusted him with the right to republish his works. ${ }^{57}$

M. S. Hrushevskyi could not ignore school issues, following and continuing the educational activities of S. F. Hrushevskyi, who introduced "...the scope ... of his school affairs and plans" 58 to little Mykhailo back in his childhood. His first pedagogical experience, gained instructing his younger brother Zakhar, was remembered by M. Hrushevskyi as an unsuccessful one, ${ }^{59}$ which was why he fully compensated his lack of pedagogical talent with organizational talent. In 1904, he invested his own money and organized a private teacher's seminary in the town of Kolomyia, and later, a similar one in the town of Rohatyn. In 1908, he became Head of the Association of Ukrainian Teachers "Uchytelska Hromada (Teacher's Community)" that supervised the periodicals Nasha shkola (Our School) and Uchytelska Hromada (Teacher's Community). In 1910, Hrushevskyi initiated the foundation of the Krai School Association where he was the head for almost two years.

53 Hrushevskyi, "Spohady," 127.

54 The textbook was first published in 1872 and in the period up to 1917 had 35 editions:

S. F. Hrushevskyi. Pervaia uchebnaia kniga tserkovnoslavianskoho yazyka. Dlia uchenikov nachalnykh uchilishch [The First Book of Instruction in Church Slavonic. For Students of Teacher's Colleges] (Moscow, 1872); S. F. Hrushevskyi. Pervaia uchebnaia kniha tserkovnoslavianskoho yazyka [The First Book of Instruction in Church Slavonic], 35th publication (Rostov-on-Don, 1917).

S. F. Hrushevskyi, "Correspondence with Publishers and Bookstores; Contracts and Accounts Regarding the Publication, Printing, and Selling of S. F. Hrushevskyi's Textbook 'The First Handbook of Church Slavonic,"' 1871-1901 [Manuscript] (Central State Historical Archives of Ukraine in Kyiv, f. 1235, desc. 1, no. 2); S. F. Hrushevskyi, "Correspondence with Bookstores and Warehouses Regarding the Storage and Dissemination of the Textbook 'The First Handbook of Church Slavonic' and Other Publications of S. F. Hrushevskyi," 1876-1890 [Manuscript] (Central State Historical Archives of Ukraine in Kyiv, f. 1235, desc. 1, no. 3, part I). 
Apart from being an editor, Hrushevskyi wrote much, including scholarly works, ${ }^{60}$ journalistic sketches, ${ }^{61}$ reviews, ${ }^{62}$ and even fictional works. ${ }^{63}$ These activities were to compensate the "literary hunger" of his childhood, as his "father was a practical person, with an active lifestyle, rather than a bookish man, while I wanted bélles-léttres, simple guides, which I needed as an integral part of my life, a relaxation for my mind, which I did not receive." 64

In 1896, Mykhailo Hrushevskyi married a teacher from Lviv, Mariia Sylvestrivna Voiakovska (1868-1948).65 Mykhailo's parents were glad to hear the news about their son's marriage since, more and more often, they expressed worries about his loneliness in their letters: "Enough of living as a 'burlaka,' being lonely." 66 However, Lviv's intelligentsia called Hrushevskyi's marriage a mésalliance and were surprised by the choice of the young and promising professor.

Even though before 1901 Hrushevskyi was unanimously elected Head of the Shevchenko Scientific Society, gradually, an opposition emerged against his candidature. More and more discontent grew among the "ordinary" members, who were no longer able to interfere in the organizational affairs of the society according to the latest statute. The inner conflict escalated, provoked by Hrushevskyi's opponents who, thinking that he was wealthy, were indignant with his high income, and even more, with the fact that he did not donate his income to the Shevchenko Scientific Society.

6o M. S. Hrushevskyi, "Kulturno-natsionalnyi rukh na Ukraini v druhii polovyni XVI viku. I [The Cultural and National Movement in Ukraine in the Second Half of the 16th Century. Part I]," Literaturnonaukovyi visnyk 41 (1908): 282-96; M. S. Hrushevskyi, "Kulturno-natsionalnyi rukh na Ukraini v druhii polovyni XVI viku. II [The Cultural and National Movement in Ukraine in the Second Half of the 16th Century. Part II]," Literaturno-naukovyi visnyk 41 (1908): 491-506; M. S. Hrushevskyi “Vyhovskyi i Mazepa [Vyhovskyi and Mazepa]," Literaturno-naukovyi visnyk 46 (19o9): 417-28.

$61 \quad$ M. S. Hrushevskyi, "Memorial Peterburzhskoi Akademii v spravi svobody ukrainskoi movy v Rosii [The Peterburg Memorial Academy in the Cause of the Freedom of the Ukrainian Language in Russia]," Literaturno-naukovyi visnyk 30 (1905): 16o-63; M. S. Hrushevskyi, "Na porozi stolittia: prysviacheno peremyshlskii ukrainsko-ruskii hromadi [On the Threshold of the Century: Dedicated to the Przemysl Ukrainian-Ruthenian Community]," Literaturno-naukovyi visnyk 13.2 (1901): 77-87; M. S. Hrushevskyi, "Ne daimosia! (Sprava ukrainskykh uchytelskykh seminarii) [Do Not Give Up! (The Case of the Ukrainian Teacher's Seminaries)]," Literaturno-naukovyi visnyk 31.2 (1905): 90-92.

62 M. S. Hrushevskyi, "Rudnytskyi. Korotka heohrafia Ukrainy (Retsenziia) [Rudnytsky. A Brief Geography of Ukraine (Review)]," Literaturno-naukovyi visnyk 52 (1910): 195-96; M. S. Hrushevskyi, "T. Shevchenko. Kobzar (Retsenziia) [T. Shevchenko. Kobzar (Review)]," Literaturno-naukovyi visnyk 37 (1907): 368; M. S. Hrushevskyi, “M. Starytskyi. Poezii (Retsenziia) [M. Starytskyi. Poetry (Review)]," Literaturno-naukovyi visnyk 41 (1908): 641-47.

63 M. S. Hrushevskyi, "Kometa (opovidannia) [Comet (Story)]," Literaturno-naukovyi visnyk 54 (1911): 284-94; M. Z. "Nich (opovidannia) [Night (Story)]," Literaturno-naukovyi visnyk 46 (1909): 288-91.

64 Hrushevskyi, "Spohady," 127.

65 Their daughter Kateryna Hrushevska (1900-1943) was an ethnosociologist, folklorist, and ethnographer.

66 H. Z. Hrushevska (Oppokova), "Letter from H. Z. Hrushevska to M. S. Hrushevskyi from 18 September 1892," [Manuscript] (Central State Historical Archives of Ukraine in Kyiv, f. 1235, desc. 1, no. 278, p. 191). 
When the revolution in the Russian Empire began (1905-1907), the situation improved on the territory of Russian Ukraine. Already in 1905, the ban on the Ukrainian language was lifted, which enabled the appearance of new Ukrainian periodicals (Hromadska dumka (Public Opinion), Khliborob (Grain Grower), Ridnyi krai (Native Land)), cultural and educational organizations ("Prosvita" (Public Education)), and which activized Ukrainian political parties (Ukrainian Social-Democratic Association, Ukrainian Social-Democratic Labor Party, Ukrainian Radical Democratic Party). Willing to take an active part in the defense of the national question in Dnieper Ukraine, M. Hrushevskyi returned to Kyiv, where he became the leader of the Ukrainian parliamentary community in the State Duma (1906). In January 1907, he moved the editorial board of Literaturno-naukovyi visnyk to Kyiv, and in the spring of 1907 became head of the newlycreated Ukrainian Scientific Society in Kyiv.

The culmination of the internal organizational conflict in the Shevchenko Scientific Society occurred surrounding an argument over the journalistic collection Nasha polityka (Our Politics), in which Hrushevskyi accused Galician public activists of a "lack of principles, a straight line, long-term program, and tactics," especially considering the Austrian authorities. ${ }^{67}$ This resulted in a conflict between the scholar and his student, Stepan Tomashivskyi, which gained resonance within academic circles. At the meeting of the Shevchenko Scientific Society of 26 December 1913, society members who united against the further leadership of M. Hrushevskyi managed to collect enough votes to change the statute (while being opposed by the head of the Society and members from Dnieper Ukraine). After these events, Professor Hrushevskyi, gave up active participation in the Shevchenko Scientific Society. The conflict in the Shevchenko Scientific Society caused Hrushevskyi to terminate his active participation in the society's business and finally return to Kyiv in the autumn of 1914.

During these difficult times, when Mykhailo Hrushevskyi had to balance between Kyiv and Lviv, he no longer had his father's support. As S. F. Hrushevskyi became older, his health gradually worsened. However, this did not influence his vital energy and the intense activities of his last years because, as Mykhailo Hrushevskyi described his father, "He was, actually, a type of a Ukrainian who has the cult of work in his blood - neither for enrichment, nor for career, but for work in itself. ... In his work, he found his joy, the poetry of work fascinated him." 68 We can assume (at least from the mood of his letters to his son Mykhailo) that the last years of Serhii Fedorovych's life were calm and happy — he was pleased not only with his work, but also with his children, who had fulfilled his expectations and had become successful, and with his grandchildren, Olha and Serhii. ${ }^{69}$

Serhii Fedorovych Hrushevskyi died at the age of 71 in Vladykavkaz on 27 January, 1901. He was buried at the First municipal cemetery of Vladykavkaz by his younger children. In the 193os, a Komsomol park was established at the place of the former cemetery. ${ }^{70}$

67 M. S. Hrushevskyi, Nasha polityka [Our Politics] (Lviv, 1911), 6.

68 Hrushevskyi, "Spohady," 125.

69 Olha Viktorivna Shamrai (1898-1955) and Serhii Viktorovych Shamrai (1900-1939), Serhii was named after his grandfather — the children of Hanna Serhiivna Hrushevska (Shamrai) and Viktor Illich Shamrai, who lived in Vladykavkaz at that time. 
Additional overt evidence of how important education was in the life of S. F. Hrushevskyi was his last will, which allocated funds "for the establishment, in Kyiv or Vladykavkaz, of a free primary men's school, named after him." Almost half of the entrusted capital was meant for the purchase or construction of the school premises, and the rest was meant "to provide the most impoverished pupils with clothes and shoes, and with textbooks, if decided by the school council." ${ }^{71}$ In addition, thanks to his donations to the Kyiv Theological Seminary and the KyivPodilsk religious school, personalized scholarships were established, "...one scholarship each, to support one state-funded pupil of our origin, of the Hrushevkyi family name, if possible." 72 Already in 1911, the Hrushevskyi family founded the Kurenivka school in Kyiv, named after S. F. Hrushevskyi. Its three-stored building in the Ukrainian modern style (on Kyrylivska Street, 164) was constructed utilizing the project of architects E.-F. Bradtman and V. H. Krychevskyi.73 At a meeting on 7-9 March 1917, the Kyiv City Duma allowed (for the first time in Kyiv) the introduction of the Ukrainian language as the language of study, and even collected a library of Ukrainian books and textbooks for this purpose.

Fulfilling his father's will was not the only concern of M. S. Hrushevskyi (he was the executor of the will). As the eldest in the family, he had to take care of his elderly mother, his younger brother Oleksandr (who was then a student at the historical and philological department of St. Volodymyr University), and his sister Hanna (who had also moved to Kyiv with her children in 1905). Distant relatives also approached Mykhailo Serhiiovych in various matters. For example, the Central State Historical Archives of Ukraine preserve letters dated 1906-1912 ${ }^{74}$ from Oleksandr (Oleksa) ${ }^{75}$ and Oleksii ${ }^{76}$ Hrushevskyi. Oleksandr, who was studying at the Kyiv Theological Seminary, asked him to intercede for the recommencement of the S. F. Hrushevskyi scholarship and to help him buy books for the library of the seminarian "Ukrainian circle," whereas Oleksii wanted to obtain a loan of two and a half thousand rubles for his university studies. Mykhailo Serhiiovych also provided for his nephews and nieces. For example, he prepared Olha Oppokova for university examinations, and in one of her letters she felt sorry that she "could not do everything that uncle wanted."77

71 Hrushevskyi, Zapovit, 19-20.

72 Hrushevskyi, Zapovit, 19.

73 See V. V. Kovalynskyi “Uchylyshche Hrushevskoho [The Hrushevskyi School]," in Metsenaty Kyieva, ed. V. V. Kovalynskyi (Kyiv: Kyi, 1998), 408-18.

M. S. Hrushevskyi, “Letters from Oleksandr and Oleksii Hrushevski (19o6-1912)," [Manuscript] (Central State Historical Archives of Ukraine in Kyiv, f. 1235, desc. 1, no. 293).

Hrushevskyi Oleksandr Ivanovych (1894-1959) was born into the family of a priest. After graduating from Kyiv Theological Seminary, he studied law at St. Volodymyr University. He then worked as a teacher at the Kyiv Artillery School. Because of his connection with the Hrushevskyi family and having received an S. F. Hrushevskyi scholarship, he was fired and evicted in 1937. From July 1941 he fought on the Southern Front. See Kucherenko et al., Ya buv yikh starshyi syn, $3 \mathrm{O}$.

76 Hrushevskyi Oleksii Hryhorovych (born in 1887 and died not earlier than 1918). After graduating from Kyiv Theological Seminary, he worked as a teacher (1908-1911). In 1911 he was consecrated as a priest at the Troitsk Church in Velikii Karashyn village, Kyiv region. After 1917 his fate is unknown.

M. S. Hrushevskyi, "Letters from Voiakovska, Mochulska O., Myklasevych O., Levytska L.," 1887-1926 [Manuscript] (Central State Historical Archives of Ukraine in Kyiv, f. 1235, desc. 1, no. 296, p. 15). 
In sum, throughout his entire life Mykhailo Hrushevskyi continued his father's tradition of strengthening family ties.

Serhii Hrushevskyi's life, which was filled with tireless work, deserves respect, and studying his biography adds many important details to our understanding of the life and work of his famous son. It is likely that Mykhailo Serhiiovych often thought of his father's prophetic advice, "God grant that you are always faithful to the current direction of your activities, a most wise and reliable direction, and, there will come a time... that you will make sure and remember me with a kind word." 78 The impact of Serhii Hrushevskyi on the formation of his son's worldview was evident both in the latter's work, and in the formation of his system of values and references. His love of "things Ukrainian," his wish to write, and his selfless labor are all part of the heritage that his father left him, and which were always at the center of his life and scholarly work.

\section{Bibliography}

Hrushevska (Oppokova), H.Z. "Letters from H. Z. Hrushevska to M. S. Hrushevskyi." Central State Historical Archives of Ukraine in Kyiv, f. 1235, desc. 1, no. 278 [Manuscript].

Hrushevskyi, M.S. “Kometa (opovidannia) [Comet (Story)].” Literaturno-naukovyi visnyk 54 (1911): 284-94.

Hrushevskyi, M.S. "Kulturno-natsionalnyi rukh na Ukraini v druhii polovyni XVI viku. I [The Cultural and National Movement in Ukraine in the Second Half of the 16th century. Part I]." Literaturno-naukovyi visnyk 41 (1908): 282-96.

Hrushevskyi, M.S. "Kulturno-natsionalnyi rukh na Ukraini v druhii polovyni XVI viku. II [The Cultural and National Movement in Ukraine in the Second Half of the 16th century. Part II]." Literaturno-naukovyi visnyk 41 (1908): 491-506.

Hrushevskyi, M.S. "Letters from Oleksandr and Oleksii Hrushevskyi." 1906-1912. Central State Historical Archives of Ukraine in Kyiv, f. 1235, desc. 1, no. 293 [Manuscript].

Hrushevskyi, M.S. "Letters from Voiakovska, Mochulska O., Myklashevych O., Levytska L.” 18871926. Central State Historical Archives of Ukraine in Kyiv, f. 1235, desc. 1, no. 296 [Manuscript].

Hrushevskyi, M.S. "Memorial Peterburzhskoi Akademii v spravi svobody ukrainskoi movy v Rosii [The Peterburg Memorial Academy in the Cause of the Freedom of the Ukrainian Language in Russia]." Literaturno-naukovyi visnyk 30 (1905): 16o-63.

Hrushevskyi, M.S. “M. Starytskyi. Poezii (Retsenziia) [M. Starytskyi. Poetry (Review)]." Literaturnonaukovyi visnyk 41 (1908): 641-47.

Hrushevskyi, M.S. "Na porozi stolittia: prysviacheno peremyshlskii ukrainsko-ruskii hromadi [On the Threshold of the Century: Dedicated to the Przemysl Ukrainian-Ruthenian Community]." Literaturno-naukovyi visnyk 13.2 (1901): 77-87.

Hrushevskyi, M. S. Nasha polityka [Our Politics]. Lviv, 1911.

Hrushevskyi, M.S. "Ne daimosia! (Sprava ukrainskykh uchytelskykh seminarii) [Do Not Give Up! (The Case of the Ukrainian Teacher's Seminaries)]." Literaturno-naukovyivisnyk 31.2 (1905): 90-92.

78 H. Z. Hrushevska (Oppokova), "Letter from H. Z. Hrushevska to M. S. Hrushevskyi from 3 January 1897," [Manuscript] (Central State Historical Archives of Ukraine in Kyiv, f. 1235, desc. 1, no. 278, p. 427 back). 
Hrushevskyi, M.S. "Rudnytskyi. Korotka heohrafiia Ukrainy (Retsenziia) [Rudnytskyi. A Brief Geography of Ukraine (Review)]." Literaturno-naukovyi visnyk $5^{2}$ (1910): 195-96.

Hrushevskyi, M.S. "Spohady [Memoirs]." Kyiv 9 (1988): 115-49; 10 (1988): 131-38; 11 (1988):120-37; 12 (1988): 116-39; 8 (1989): 102-54; 9 (1989): 108-49; 10 (1989): 122-58; 11 (1989): 113-55; 12 (1989): 111-32; 2 (1993): 109-25; 3 (1993): 131-42.

Hrushevskyi, M.S. “T. Shevchenko. Kobzar (Retsenziia) [T. Shevchenko. Kobzar (Review)].” Literaturno-naukovyi visnyk 37 (1907): 368.

Hrushevskyi, M.S. "Vyhovskyi i Mazepa [Vyhovskyi and Mazepa]." Literaturno-naukovyi visnyk 46 (1909): 417-28.

Hrushevskyi, S.F. "Correspondence with Publishers and Bookstores; Contracts and Accounts Regarding the Publication, Printing, and Selling of S. F. Hrushevskyi's Textbook 'The First Handbook of Church Slavonic." 1871-1901. Central State Historical Archives of Ukraine in Kyiv, f. 1235, desc. 1, no. 2 [Manuscript].

Hrushevskyi, S.F. "Istoricheskiie svedeniia o chyne mirovareniia [Historical Information About the Mass of the Chrism]." Rukovodstvo dlia selskikh pastyrei 44 (1863): 314-20.

Hrushevskyi, S.F. "Krestnye khody v Russkoi Tserkvi [Processions of the Cross in the Russian Church]." Rukovodstvo dlia selskikh pastyrei 46 (1863): 482-95; 49 (1863): 617-31.

Hrushevskyi, S.F. "K voprosu ob izyskanii sposobov k uluchsheniiu materialnoho byta dukhovnykh uchilishch [Regarding the Question of the Search for the Ways of Material Improvement in Theological Schools]." Rukovodstvo dlia selskikh pastyrei 47 (1862): 442-43.

Hrushevskyi, S.F. "Correspondence with Bookstores and Warehouses Regarding the Storage and Dissemination of the Textbook 'The First Handbook of Church Slavonic' and Other Publications of S. F. Hrushevskyi." 1876-189o. Central State Historical Archives of Ukraine in Kyiv, f. 1235, desc. 1, no. 3, part I [Manuscript].

Hrushevskyi, S.F. "Correspondence with Bookstores and Warehouses Regarding the Storage and Dissemination of the Textbook 'The First Handbook of Church Slavonic' and Other Publications of S. F. Hrushevskyi." 1876-189o. Central State Historical Archives of Ukraine in Kyiv, f. 1235, desc. 1, no. 4, part II [Manuscript].

Hrushevskyi, S.F. "Obriady Pravoslaviia pri moskovskikh Mitropolitakh i Patriarkhakh Vserossiiskikh [Orthodox Ceremonies of Moscow Metropolitans and Patriarchs]." Rukovodstvo dlia selskikh pastyrei 11 (1864): 367-77.

Hrushevskyi, S.F. "O dukhovnom zaveshchanii [About Spiritual Testament]." Rukovodstvo dlia selskikh pastyrei 51 (1864): 653-58; $5^{2}$ (1864): 733-44.

Hrushevskyi, S.F. "O nekotorykh sviatochnykh obychaiakh prostoho naroda [About Some Holy Customs of Commoners]." Rukovodstvo dlia selskikh pastyrei 52 (1861): 623-42.

Hrushevskyi, S.F. "Ostatki yazychestva v nashem prostom narode [Remains of Paganism Among Our Common Folk].” Rukovodstvo dlia selskikh pastyrei 41 (1860): 131-50.

Hrushevskyi, S.F. "Otmenennye tserkovnye obriady i chinoposledovaniia vremen patriarshestva v Rossii [Canceled Church Ceremonies and Clerical Ranks in the Times of the Patriarchate in Russia]." Rukovodstvo dlia selskikh pastyrei 23 (1863): 173-9o; 28 (1863): 363-80; 35 (1863): 1-19; 38 (1863): 133-46; 39 (1863): 171-81. 
Hrushevskyi, S. F. Pervaia uchebnaia kniga tserkovnoslavianskoho yazyka. Dlia uchenikov nachalnykh uchilishch [The First Book of Instruction in Church Slavonic. For Students of Teacher's Colleges]. Moscow, 1872.

Hrushevskyi, S. F. Pervaia uchebnaia kniga tserkovnoslavianskoho yazyka [The First Book of Instruction in Church Slavonic]. 35th publication. Rostov-on-Don, 1917.

Hrushevskyi, S.F. "Po povodu prostonarodnykh primet v den Novogo goda [About New Year's Superstitions Among Commoners]." Rukovodstvo dlia selskikh pastyrei 1 (1862): 6-24.

Hrushevskyi, S.F. "Po voprosu o narodnom obrazovanii [On the Question of Public Education]." Rukovodstvo dlia selskikh pastyrei 42 (1863): 319-25.

Hrushevskyi, S.F. "Prazdnik Bohoiavleniia v Rossii v XVI i XVII stoletiiakh [The Feast of the Epiphany in Russia in the 16 th and 17 th Centuries]." Rukovodstvo dlia selskikh pastyrei 2 (1864): 33-51.

Hrushevskyi, S.F. "Sovremennye prostonarodnye verovania otnositelno vedunstva i koldovstva [Modern Commoner's Beliefs Regarding Witchcraft and Magic]." Rukovodstvo dlia selskikh pastyrei 21 (1865): 105-20; 25 (1865): 263-80.

Hrushevskyi, S.F. "Suevernaia vstrecha prazdnika Paskhi u yuzhno-russkikh prostoliudinov [Easter Superstitions Among South Russian Commoners]." Rukovodstvo dlia selskikh pastyrei 18 (1862): 6-16.

Hrushevskyi, S.F. "Svidotstvo pro narodzhennia, posluzhni spysky ta biohrafiia [Birth Certificate, Service Record and Biography]." 1830-1901. Central State Historical Archives of Ukraine in Kyiv, f. 1235, desc. 1, no. 1, pp. 14-25 [Manuscript].

Hrushevskyi, S.F. "Zapovit [Testament]." 1892. Central State Historical Archives of Ukraine in Kyiv, f. 1235, desc. 1, no. 11 [Manuscript].

Kleyzun, L. "Do biohrafii Oleksandra Hrushevskoho [On the Biography of O. Hrushevskyi]." Kraieznavstvo 1-2 (2000): 65-69.

Kovalynskyi, V.V. "Uchylyshche Hrushevskoho [The Hrushevskyi School]." In Metsenaty Kyieva, edited by V. V. Kovalynskyi, 408-18. Kyiv: Kyi, 1998.

Kucherenko, M. O. "Dilu semu posviatyv vin vseiu dusheiu [Matters that He Devoted His Heart and Soul to]." In Ya buv yikh starshyi syn (simia Mykhaila Hrushevskoho), edited by M. O. Kucherenko, S. M. Pankova and H. V. Shevchuk, 74-123. Kyiv: Kyi, 2006.

Kucherenko, M. O., S. M. Pankova, and H. V. Shevchuk. Ya buv yikh starshyi syn (simia Mykhaila Hrushevskoho) [I Was Their Eldest Son (the Family of Mykhailo Hrushevskyi)]. Kyiv: Kyi, 2006.

Kucherenko, M.O. "Serhii Fedorovych Hrushevskyi: etapy zhyttia i diialnosti na nyvi pedahohiky [Serhii Fedorovych Hrushevskyi: Stages of Life and Work in the Field of Pedagogy]." Ukrainoznavstvo 1 (2016): 33-45.

Kuzmina, S.L. "Lebedyntsev Feofan Havrylovych." In Kyivska dukhovna akademiia v imenakh, vol. 2, edited by M. Tkachuk, 50-53. Kyiv:Vydavnychyi dim “Kyievo-Mohylianska akademiia," 2016.

"Nekroloh [Obituary] [Hrushevskyi S. F.]." Literaturno-naukovyi visnyk 13 (1901): 220.

M. Z. "Nich (opovidannia) [Night (Story)]." Literaturno-naukovyi visnyk 46 (1909): 288-91.

"Vidozva do ukraiintsiv u spravi zboru istorychnyh pamiatok [A Response to Ukrainians on the Issue of the Gathering Relics from the Past]." Khronika Naukovoho Tovarystva Imeni Shevchenka 8.4 (1901): 18. 
Yaremenko, M.V. "Kryzhanovskyi Yukhym/Yevfymii Mykhailovych." In Kyivska dukhovna akademiia v imenakh, vol. 1, edited by M. Tkachuk, 722-25. Kyiv: Vydavnychyi dim "KyievoMohylianska akademiia," 2015.

Yurynets, Ya.I. "Hrushevskyi Serhii Fedorovych." In Kyivska dukhovna akademiia v imenakh, vol. 1, edited by M. Tkachuk, 410-12. Kyiv: Vydavnychyi dim "Kyievo-Mohylianska akademiia," 2015 .

Zhuravlev, S.A. "Stanovlennia i rozvytok osvitianskoi diialnosti Serhiia Fedorovycha Hrushevskoho u druhii polovyni XIX st. [The Establishment and Development of the Educational Activities of S. F. Hrushevskyi in the Second Half of the 19th Century]." Zbirnyk naukovykh prats Kharkivskoho natsionalnoho pedahohichnoho universytetu imeni H. S. Skovorody 48 (2013): 191-96.

Zhurnal zasedanii Konferentsii Kievskoi dukhovnoi akademiiza 1859 god [Conference Journal of the Kyiv Theological Academy of in 1859]. Manuscript Institute, V. I. Vernadskyi National Library of Ukraine, f. 175, no. 59/7 [Manuscript].

Zhurnal zasedanii Konferentsii Kievskoi dukhovnoi akademii za 1860 god [Conference Journal of the Kyiv Theological Academy in 186o]. Manuscript Institute, V. I. Vernadskyi National Library of Ukraine, f. 175, no. 59/8 [Manuscript].

Yaryna Yurynets is a Professor's assistant at the Department of Philosophy and Religious Studies at the National University of Kyiv-Mohyla Academy. Her research interests include the history of philosophy, especially zoth century Ukrainian philosophy, philosophical discussions of the 1920s-193os, and repressions against the Ukrainian intelligentsia. She is a contributing author of the Kyivska dukhovna akademiia v imenakh (Kyiv Theological Academy in Names) encyclopedia (Kyiv: Vydavnychyi dim "Kyievo-Mohylianska akademiia," vol. 1 (2015), vol. 2 (2016)). Her major publications include: Novi materialy do zhyttiepysu Volodymyra Yuryntsia: studentski roky u Lvivskomu ta Videnskomu universytetakh [New Material on the Biography of Volodymyr Yurynets: His Student Years at Lviv and Vienna Universities] (2010), Bilia dzherel "krytyky suchasnoi burzhuaznoi filosofi" (do istorii ukrainskoi filosofii radianskoi doby) [At the Sources of "Criticism of Modern Bourgeois Philosophy" (on the History of Ukrainian Philosophy in the Soviet Period)] (2012), Semen Semkovskyi i stanovlennia filosofii pryrodoznavstva v Ukraini u 1920-1930-kh rokakh [Semen Semkovskyi and the Establishment of the Philosophy of Natural Sciences in Ukraine in the 1920s-1930s] (2016). 